\title{
KESIAPAN BERWIRAUSAHA SISWA SMK KOMPETENSI TEKNIK KOMPUTER DAN JARINGAN DI GUNUNGKIDUL
}

\author{
Sri Supraba \\ SMKN 1 Saptosari \\ probosucipto@gmail.com, \\ Dwi Rahdiyanta \\ Universitas Negeri Yogyakarta \\ dwi_rahdi@yahoo.com
}

\begin{abstract}
Abstrak
Tujuan Penelitian ini adalah untuk mengungkapkan pengaruh pengetahuan kewirausahaan, pengalaman praktik kerja industri, dan lingkungan keluarga terhadap kesiapan berwirausaha siswa.Penelitian ini merupakan penelitian ex-post facto. Populasi penelitian adalah siswa SMK Kompetensi Keahlian Teknik Komputer dan Jaringan di Kabupaten Gunungkidul, yang berjumlah 221 siswa. Sampel penelitian sebanyak 135 responden. Hasil penelitian menunjukkan hasil sebagai berikut: 1) terdapat pengaruh yang positif dan signifikan antara pengetahuan kewirausahaan dengan kesiapan berwirausaha $\left(r_{x x y}=0,53 ; p<0,05\right)$; 2) terdapat pengaruh yang positif dan signifikan antara pengalaman praktik kerja industri dengan kesiapan berwirausaha $\left.\left(r_{x 2 y}=0,77 ; p<0,05\right) ; 3\right)$ terdapat pengaruh yang positif dan signifikan antara lingkungan keluarga dengan kesiapan berwirausaha $\left.\left(r_{x 3 y}=0,37\right) ; 4\right)$ terdapat pengaruh yang positif dan signifikan antara pengetahuan kewirausahaan, pengalaman praktik kerja industri, dan lingkungan keluarga dengan kesiapan berwirausaha $\left(r_{x l}, r_{x 2} r_{x 3 y}=0,56\right)$. Dari hasil ini dapat disimpulkan bahwa pengetahuan kewirausahaan, pengalaman paktik kerja industri, dan lingkungan keluarga secara bersama-sama mampu memberikan pengaruh sebesar $56 \%$ terhadap kesiapan berwirausaha.
\end{abstract}

Kata Kunci : kesiapan, berwirausaha, teknik komputer dan jaringan

\section{ENTREPRENEURSHIP READINESS OF STUDENTS VOCATIONAL HIGH SCHOOL MAJORING IN NETWORK AND COMPUTER ENGINEERING SKILLS PROGRAM IN GUNUNGKIDUL REGENCY}

\begin{abstract}
This study aims to reveal the effects of entrepreneurship knowledge, industrial job practicum experience, and family environment on the entrepreneurial readiness students. This was an ex post facto study. The research population comprised students of Computer an Network Engineering Expertise Competence in VHSs in Gunungkidul Regency with a total of 221 students. The research sample, consisting of 135 respondents. Base on the research results show. 1) There is a positive and significant effect of the entrepreneurship knowledge on the entrepreneurial readiness $\left(r_{x I y}=\right.$ $0.53 ; p<0.05)$. 2) There is positive and significant effect of th industrial job practicum experience on the entrepreneurial readiness $\left(r_{x 2 y}=0.77 ; p<0.05\right)$. 3) There is positive and significant effect of the family environment on the entrepreneurial readiness $\left(r_{x 3 y}=0.37 ; p<0.03\right)$. 4) There are positive and significant effect of the entrepreneurship knowledge, industrial job practicum experience, and family environment on the entrepreneurial readiness $\left(r_{x 1}, r_{x 2}, r_{x 3 y}=0.56\right)$. Base on the result entrepreneurship knowledge, industrial job practicum experience, and family environmentas an aggregate have effects of $56 \%$ on the entrepreneurial readiness.
\end{abstract}

Keywords: Readiness, entrepreneurship, networks and computer engineering 


\section{PENDAHULUAN}

Tenaga kerja merupakan masalah krusial di Indonesia. Secara nasional angka pengangguran di Indonesia masih tergolong tinggi. Penyerapan tenaga kerja hingga februari 2012 masih didominasi oleh pekerja berpendidikan rendah yaitu sekolah dasar ke bawah sebesar 55,51 juta orang atau 49,21 persen. Hal ini dapat dilihat dari berita resmi Badan Pusat Statistik dalam situs http:// www.bps.go.id/brs_file/naker_07mei12.pdf (7 mei 2012). Dari data tersebut di atas untuk lulusan Sekolah Menengah Kejuruan (SMK) yang belum terserap pada dunia kerja sebesar 9,43 juta orang.

Yogyakarta sebagai kota pendidikan juga masih menghadapi masalah pengangguran. Menurut data Departemen Tenaga Kerja dan Transmigrasi Daerah Istimewa Yogyakarta seperti yang dirilis pada situs http://www.nakertrans.jogjaprov.go.id

Juni 2012) menyatakan pada tahun 2011 angka pencari kerja yang belum ditempatkan sebanyak 56.489 orang yang tersebar di 5 kabupaten/kota dengan perincian kota Yogyakarta sebanyak 8.437 orang, kabupaten Bantul sebanyak 7.706 orang, kabupaten Sleman sebanyak 30.683 orang, kabupaten Kulon Progo sebanyak 758 orang dan Kabupaten Gunungkidul sebanyak 8.905 orang. Dari lowongan yang terdaftar sebanyak 24.208 orang dan yang belum terisi sebanyak 853 orang. Dari angka tersebut menunjukkan tidak seimbangnya kebutuhan tenaga kerja dengan jumlah pencari kerja itu sendiri.

Gunungkidul secara geografis merupakan wilayah yang didominasi dengan daerah kawasan perbukitan karst. Wilayah selatan didominasi oleh kawasan perbukitan karst yang banyak terdapat goa-goa alam dan juga sungai bawah tanah yang mengalir. Dengan kondisi tersebut menyebabkan kondisi lahan kurang subur yang berakibat budidaya pertanian di kawasan ini kurang optimal. Secara makro ekonomi kabupaten Gunungkidul perekonomiannya di dominasi sektor pertanian. Hal ini bertolak belakang dengan kondisi alam yang kurang subur untuk lahan pertanian sehingga hasil dari pertanian kurang optimal.

Kondisi alam yang tidak bersahabat menyebabkan sebagian besar penduduk Gunungkidul memilih merantau ke kota-kota besar Jawa seperti Jakarta dan Surabaya. Selain menjadi pembantu rumah tangga banyak diantara warga Gunungkidul yang bekerja menjadi buruh pabrik. Selain faktor geografis di atas ada beberapa faktor yang menyebabkan warga Gunungkidul merantau yaitu ketersediaan lapangan kerja, kemiskinan dan informasi lapangan kerja. Hal itulah yang mendorong keinginan warga untuk mengadu nasib di kota besar selain daerahnya.

Rendahnya jenjang pendidikan, tidak seimbangnya antara jumlah pencari kerja dan lowongan pekerjaan, minimnya keterampilan yang dimiliki dalam bekerja dan minimnya informasi untuk mendapatkan pekerjaan masih menjadi beberapa penyebab tingginya angka pengangguran di Indonesia.

Salah satu jurusan yang meng-gunakan dari Standar Kompetensi Nasional bidang keahlian jaringan komputer dan sistem administrasi adalah Teknik Komputer dan Jaringan (TKJ). Jurusan ini mempelajari tentang cara merakit komputer, instalasi sistem operasi, menangani permasalahan pada komputer, membuat jaringan komputer baik Local Area Network (LAN) maupun Wide Area Network (WAN). Dari hasil pra observasi yang dilakukan pada tiga Sekolah Menengah Kejuruan yang mempunyai jurusan TKJ disampaikan bahwa peminat untuk jurusan ini dari tahun ke tahun mengalami kenaikan, sehingga perlu pengelolaan yang baik untuk jurusan ini. Karena dengan pengelolaan jurusan yang baik maka akan terwujud harapan orang tua siswa untuk mendapatkan pekerjaan sesuai dengan jurusanya. Selain itu pengelolaan yang baik akan meningkatkan citra jurusan TKJ sebagai jurusan baru yang kompetitif pada saat ini.

Dari hasil pra penelusuran tamatan kompetensi keahlian Teknik Komputer dan Jaringan yang dilakukan pada tiga Sekolah Menengah Kejuruan di Gunungkidul pada tahun 2012, yaitu SMKN 1 Saptosari, SMKN 1 Nglipar, SMKN 1 Ngawen didapatkan data bahwa prosentase lulusan yang bekerja tidak sesuai dengan kompetensinya sejumlah 72 orang dari 142 siswa atau 50,7\%, untuk yang bekerja sesuai dengan kompetensinya sejumlah 16 orang dari 142 lulusan atau 11,27\%, sedangkan yang belum bekerja sejumlah 26 orang dari 142 atau $18,31 \%$, dan 28 orang atau $19,72 \%$ yang melanjutkan studi. Dari hasil penelusuran ini berarti bahwa lulusan 
kompetensi keahlian teknik komputer dan jaringan belum terserap secara signifikan sesuai dengan kompetensinya.

Dari materi kurikulum yang diberikan pada kompetensi keahlian jaringan dan komputer semua tidak terlepas dari teknologi informasi dan komunikasi. Saat ini teknologi informasi dan komunikasi sudah menjadi gaya hidup (life style) dari masyarakat di sekitar kita. Instansi-instasi pemerintah seperti kelurahan, kecamatan, sekolah-sekolah sampai tingkat rukun tetangga tidak terlepas dari yang namanya teknologi informasi dan komunikasi khusunya komputer.

Dari pemaparan tersebut terlihat bahwa siswa lulusan kompetensi keahlian teknik komputer dan jaringan memiliki potensi untuk bekerja sesuai dengan kompetensinya sehingga dapat mengurangi jumlah pengangguran. Meningkatnya kebutuhan dan penggunaan alat teknologi seperti komputer, laptop dan sebagainya yang sering rusak, memunculkan peluang jasa untuk membuka usaha dengan menjual atau perbaikan pada bidang komputer, laptop dan sebagainya.

Pemerintah melalui Kementrian Pendidikan Nasional telah memasukan kurikulum mata pelajaran Kewirausahaan pada tingkat Sekolah Menengah Kejuruan. Tujuan mata pelajaran kewirausahaan adalah memahami dunia usaha dalam kehidupan sehari-hari, berwirausaha dalam bidangnya serta mengaktualisasikan sikap dan perilaku berwirausaha (Akhmad Sudrajat, 2008: 38). Dari pendidikan kewirausahaan ini pula siswa dibekali bagaimana mengelola sebuah usaha mulai bagaimana berkomunikasi dengan pelanggan, mengelola keuangan dan mengelola informasi untuk mengambil keputusan.

Perilaku kewirausahaan tidak harus dimiliki oleh orang-orang yang telah bekerja atau mempunyai usaha, akan tetapi perlu disiapkan mulai dari pendidikan termasuk pendidikan kejuruan. Pada dasarnya manusia mempunyai jiwa yang kreatif dan inovatif dalam kehidupanya. Melalui belajar kewirausahaan siswa diharapkan mampu mengubah pola pikir dari mencari pekerjaan menjadi menciptakan pekerjaan.

Pola pendidikan kejuruan sudah mengembangkan pengajaran yang mempersiapkan manusia wirausaha seperti pembelajaran kewirausahaan, namun hal itu perlu diperdalam dengan sinergi, kerjasama yang efektif dan efisien antara sekolah, keluarga, masyarakat pemakai industri tenaga kerja, dan dunia ekonomi pada umumnya. Sinergi ini diharapkan terus menerus tumbuh dan berkembang dengan memiliki dasar mengembang ide dan meraih peluang sebanyak-banyaknya. Kerja sama ini yang dimaksud adalah adanya Pendidikan Sistem Ganda yang tertuang dalam program praktik kerja industri (prakerin).

Praktik Kerja Industri adalah ikut belajar bekerja dalam kegiatan usaha atau bisnis wirausaha dengan perusahaan tertentu pada bidang tertentu pula. Dengan perkataan lain, praktik kerja industri adalah ikut bekerja usaha yang diakui berstandar kurikulum tertentu dalam suatu perusahaan yang telah ditentukan. Pemahaman ini menempatkan siswa memiliki pemahaman dasar dari bidangbidang yang dipelajari dengan standar-standar kerja yang telah ditetapkan. praktik kerja industri mampu melahirkan keberhasilankeberhasilan mengembangkan ide dan menciptakan peluang. Secara umum dapat dikatakan, jika mereka menjadi wirausaha maka akan menjadi orang yang memiliki potensi untuk berprestasi.

\section{METODE PENELITIAN}

\section{Jenis Penelitian}

Pada penelitian ini merupakan penelitian survey dengan pendekatan ex-post facto dengan menguji apa yang telah terjadi pada subjek. Tujuan penelitian ini adalah untuk menyelidiki apakah satu atau lebih kondisi yang sudah terjadi mungkin menyebabkan perbedaan perilaku pada subjek. Dengan kata lain, penelitian ini untuk mengungkapkan pengaruh yang terjadi antar kelompok subjek (dalam variabel independen) dengan variabel dependen.

\section{Tempat Penelitian dan Waktu Penelitian}

Penelitian dilakukan pada SMK Kelompok Kompetensi Keahlian Teknik Komputer dan Jaringan di kabupaten Gunungkidul. Jumlah SMK Kelompok Kompetensi Keahlian Teknik Komputer dan Jaringan di kabupaten Gunungkidul berjumlah 7 (tujuh) SMK terkareditasi A dan B, terdiri dari 5 (lima) SMK Negeri dan 2 (dua) SMK Swasta. Waktu penelitian dilaksanakan pada bulan maret 2013. 


\section{Populasi dan Sampel Penelitian}

\section{Populasi}

Populasi dalam penelitian ini adalah seluruh siswa SMK di kabupaten Gunungkidul yang mempunyai kompetensi keahlian teknik komputer dan jaringan. Sumber data dalam penelitian ini adalah siswa kelas XII. Pemilihan siswa kelas XII sebagai sumber data penelitian karena siswa kelas XII sudah melaksanakan praktik kerja industri (prakerin). Berdasarkan data rekap peserta ujian nasional SMK tahun ajaran 2012/2013 di kabupaten Gunungkidul terdapat 5 (lima) SMK Negeri dan 2 (dua) SMK swasta dengan jumlah 405 siswa.

\section{Sampel}

Dari 7 (tujuh) SMK di kabupten Gunungkidul yang mempunyai kompetensi keahlian teknik komputer dan jaringan diambil 4 SMK sebagai sub-populasi dengan jumlah seluruh siswa sebanyak 221 siswa dengan teknik area sampling. Teknik area sampling dimaksudkan untuk mengambil wakil dari setiap wilayah geografis yang ada. (Riduwan, 2006 : 244). Ke empat sekolah tersebut adalah SMKN 1 Saptosari mewakili wilayah barat, SMKN 1 Girisubo mewakili wilayah selatan, SMK 45 mewakili wilayah timur, dan SMKN 1 Nglipar mewakili wilayah Utara. Penentuan jumlah sampel pada penelitian ini dengan membandingkan 2 cara yaitu dengan menggunakan nomogram Harry King dan dengan menggunakan tabel penentuan jumlah sampel yang dikembangkan oleh Isaac dan Michael. Berdasarkan nomogram Harry King dengan jumlah populasi 221 pada taraf 5\% maka didapatkan persentase populasi yang diambil sebagai sampel adalah sebanyak 56\% atau 124 responden. Sedangkan berdasarkan tabel penentuan jumlah sampel yang dikembangkan oleh Isaac dan Michael dengan populasi sebanyak 221 pada taraf 5\% didapatkan sampel sebanyak 135. Dengan demikian maka peneliti mengambil sampel yang terbanyak yaitu 135 responden.

Perhitungan jumlah sampel dilakuan dengan cara membagi jumlah populasi pada area tertentu dengan jumlah populasi keseluruhan kemudian hasilnya dikalikan dengan jumlah sampel secara keseluruhan. Contoh perhitungan sederhana dari sampel tersebut misalnya pada SMKN 1 Sptosari dengan jumlah siswa 69 orang, maka jumlah sampel $=(67 / 221) \times 135=41$ siswa. Adapun hasil perhitungan tersebut didapatkan data pada masing-masing sekolah sebagai berikut:

\section{Variabel Penelitian}

Berdasarkan kerangka pemikiran dan hipotesis yang diajukan, maka variabel dalam penelitian ini terdiri dari tiga variabel independen yaitu pengetahuan kewirausahaan (X1), lingkungan keluarga (X2) dan pengalaman Praktek Kerja Industri (X3) serta satu variabel dependen yaitu kesiapan berwirausaha (Y).

\section{Teknik dan Instrumen Pengumpulan Data}

Teknik pengumpulan data yang digunakan adalah dengan angket yaitu pengumpulan data melalui penyebaran seperangkat pertanyaan tertulis kepada responden yang menjadi anggota sampel penelitian.

\section{Teknik Analisis Data}

Teknik analisis data dalam penelitian ini menggunakan statistik deskriptif dan statistik inferensial. Statistik deskriptif adalah statistik yang digunakan untuk menganalisis data dengan cara mendeskripsikan atau menggambarkan data yang telah terkumpul sebagaimana adanya tanpa bermaksud membuat kesimpulan yang berlaku untuk umum atau generalisasi (Sugiyono, 2011: 207). Kegiatan yang berhubungan dengan statistik deskriptif adalah penyajian data melalui tabel,diagram, menghitung mean (skor rerata), modus, median dan simpangan baku. Statistik inferensial adalah teknik statistik yang digunakan untuk menganalisis data sampel dan hasilnya diberlakukan untuk populasi. Sebelum data dianalisis dengan menggunakan statistik deskriptif dan statistik inferensial maka dilakukan uji persyaratan analasis yang meliputi Uji Normalitas, Uji Linieritas, dan Uji Multikolinieritas. Analisis data dalam penelitian ini menggunakan bantuan software SPSS 18.

\section{Statistik Deskriptif}

Data di deskripsikan dengan mentabulasikan data menurut masing-masing variabel. Dengan bantuan software SPSS 18 akan diperoleh harga rerata $(\mathrm{M})$, Median (Me), Modus (Mo) dan Simpangan Baku (SB). Untuk mendeskripsikan atau mengetahui kecende- 
rungan kesiapan berwirausaha, pengetahuan kewirausahaan, pengalaman praktik kerja industri dan lingkungan keluarga digunakan kategorisasi menurut Azwar (2012: 148).

\section{Statistik Inferensial}

Pengolahan data dalam tahap ini dibagi dalam dua bagian yaitu menggunakan teknik regresi linier sederhana dan teknik regresi linier berganda. Teknik regresi linier sederhana digunakan untuk membuktikan hipotesis kesatu, hipotesis kedua, hipotesis ketiga. Sedangkan teknik regresi linier berganda digunakan untuk membuktikan hipotesi keempat.

\section{a. Teknik Regresi Linier Sederhana}

Analisis regresi linier sederhana adalah hubungan hubungan fungsional ataupun kausal satu variabel independen dengan satu variabel dependen (Sugiyono, 2012: 261). Analisis ini untuk mengetahui arah hubungan antara variabel independen dengan variabel dependen apakah positif atau negatif dan untuk memprediksi nilai dari variabel dependen apabila nilai variabel independen mengalami kenaikan atau penurunan. Data yang digunakan biasanya berskala interval atau rasio.

\section{b. Teknik Regresi Linier Berganda}

Analisis regresi linier berganda adalah bagaiamana keadaan (naik turunya) variabel dependen, bila dua atau lebih variabel independen sebagai faktor prediktor dimanipulasi. Analisis ini untuk mengetahui arah hubungan antara variabel independen dengan variabel dependen apakah masing-masing variabel independen berhubungan positif atau negatif dan untuk memprediksi nilai dari variabel dependen apabila nilai variabel independen mengalami kenaikan atau penurunan.

\section{Persyaratan Analisis}

Pengujian persyaratan analisis dilakukan untuk mengetahui apakah data yang dikumpulkan memenuhi syarat untuk dianalisis dengan statistik yang digunakan. Teknik analisis yang digunakan dalam penelitian ini adalah analisis regresi berganda (multiple regression analysis). Model regresi akan berlaku jika memenuhi asumsi utama yaitu normalitas, linieritas, multikolinieritas.

\section{a. Uji Normalitas}

Uji normalitas digunakan untuk mengetahui apakah data yang bersangkutan ber- distribusi normal atau tidak. Untuk menguji normalitas menggunakan rumus chi kuadrat dengan taraf signifikansi 5\%.

\section{b. Uji Linieritas}

Uji ini dimaksudkan untuk mengetahui apakah masing-masing variabel bebas sebagai prediktor mempunyai hubungan linier atau tidak dengan variabel terikat.

\section{c. Uji Multikolinieritas}

Uji Multikolinieritas digunakan untuk mengetahui ada tidaknya hubungan antara masing-masing variabel bebas. Apabila terjadi multikolinieritas pada persamaan regresi dapat diartikan kenaikan variabel bebas (Xi) dalam memprediksi variabel terikat (Y) akan diikuti variabel bebas (Xi) yang lain (yang terjadi multikolinieritas).

\section{Uji Hipotesis}

Pengujian hipotesis pada penelitian ini menggunakan analisis regresi ganda. Sebagai kriteria penerimaan dan penolakan digunakan tingkat signifikansi 5\%, sedangkan untuk mengetahui korelasi masing-masing variabel bebas dengan variabel terikat, serta untuk mengetahui besarnya pengaruh masing-masing variabel bebas terhadap variabel terikat digunakan analisis regresi sederhana.

\section{HASIL DAN PEMBAHASAN}

\section{Deskripsi Data}

Pada bagian ini disajikan deskripsi data hasil penelitian, pengujian persyaratan analisis, analisis data penelitian, pengujian hipotesis, dan pembahasan hasil penelitian. Berdasarkan hasil penelitian yang dilakukan maka, data yang diperoleh di lapangan, dideskripsikan untuk pengaruh variabel bebas dengan variabel terikat. Deskripsi data dari masingmasing variabel tersebut adalah sebagai berikut:

\section{Kesiapan Berwirausaha}

Berdasarkan pengolahan data secara statistik deskriptif dapat di deskripsikan bahwa pada variabel kesiapan berwirausaha dari 135 siswa, 91 siswa atau 67,4\% Siswa memiliki kesiapan berwirausaha sangat tinggi, 44 siswa atau $32,6 \%$ Siswa memiliki kesiapan berwirausaha kategori tinggi. Dari histogram dan tabel distribusi frekuensi data variabel 
kesiapan berwirausaha menunjukan bahwa kesiapan berwirausaha siswa kompetensi keahlian teknik komputer dan jaringan di Kabupaten Gunungkidul dilihat dari distribusi frekuensi maupun rata-rata termasuk dalam kategori sangat tinggi yang ditunjukan oleh persentase skor tersebut.

\section{Pengetahuan Kewirausahaan}

Berdasarkan pengolahan data secara statistik deskriptif dapat dapat di deskripsikan bahwa pada variabel pengetahuan kewirausahaan dari 135 siswa, 100 siswa atau $74 \%$ siswa memiliki pengetahuan kewirausahaan sangat tinggi, 35 siswa atau $26 \%$ siswa memiliki pengetahuan kewirausahaan kategori tinggi. Dari histogram dan tabel distribusi frekuensi data variabel pengetahuan kewirausahaan menunjukan bahwa pengetahuan kewirausahaan siswa kompetensi keahlian teknik komputer dan jaringan di Kabupaten Gunungkidul dilihat dari distribusi frekuensi maupun rata-rata termasuk dalam kategori sangat tinggi yang ditunjukan oleh persentase skor tersebut.

\section{Pengalaman Praktik Kerja Industri}

Berdasarkan pengolahan data secara statistik deskriptif dapat dapat di deskripsikan bahwa pada variabel pengalaman prakerin dari 135 siswa, 88 siswa atau 65,2\% Siswa memiliki pengalaman prakerin sangat tinggi, 47 siswa atau 34,8\% Siswa memiliki pengalaman prakerin kategori tinggi. Dari histogram dan tabel distribusi frekuensi data variabel pengalaman prakerin menunjukan bahwa pengalaman prakerin siswa kompetensi keahlian teknik komputer dan jaringan di Kabupaten Gunungkidul dilihat dari distribusi frekuensi maupun rata-rata termasuk dalam kategori sangat tinggi yang ditunjukan oleh persentase skor tersebut.

\section{Lingkungan Keluarga}

Berdasarkan pengolahan data secara statistik deskriptif dapat dapat di deskripsikan bahwa pada variabel lingkungan keluarga dari 135 siswa, 40 siswa atau $29,6 \%$ siswa memiliki lingkungan keluarga sangat tinggi, 81 siswa atau $60 \%$ siswa memiliki lingkungan keluarga kategori tinggi, sebanyak 13 siswa atau 9,7\% memiliki lingkungan keluarga dalam kategori rendah dan 1 siswa atau 0,7\% memiliki kategori sangat rendah. Dari histogram dan tabel distribusi frekuensi data variabel lingkungan keluarga menunjukan bahwa lingkungan keluarga termasuk dalam kategori tinggi yang ditunjukan oleh persentase skor tersebut.

\section{Persyaratan Analisis}

Hasil pengujian persyaratan teknik analisis regresi ganda diuraikan sebagai berikut :

\section{Normalitas}

Tabel 1. Rangkuman Hasil Uji Normalitas Data

\begin{tabular}{lll}
\hline Variabel & df & Sig. \\
\hline KesiapanBerwirausaha & 135 & 0,085 \\
PengetahuanKWU & 135 & 0,072 \\
PengalamanPrakerin & 135 & 0,062 \\
LingkunganKeluarga & 135 & 0,057 \\
\hline
\end{tabular}

Pada tabel 1 diatas menunjukan bahwa Kesiapan Berwirausaha (Y) memiliki nilai asymp. Sig. (p) sebesar 0,085; Pengetahuan Kewirausahaan (X1) memiliki nilai asymp. Sig. (p) sebesar 0,072 ; Pengalaman Prakerin (X2) memiliki nilai asymp. Sig. (p) sebesar 0,062 ; Lingkungan Keluarga (X3) memiliki nilai asymp. Sig. (p) 0,057. Dengan demikian dapat disimpulkan bahwa data kesiapan berwirausaha, pengetahuan kewirausahaan, pengalaman prakerin dan lingkungan keluarga berdistribusi normal.

\section{Uji Linieritas}

Berdasarkan hasil uji linieritas dapat diketahui bahwa hubungan antara masingmasing variabel independen dengan variabel dependen adalah linier. Hal ini ditunjukan dengan nilai signifikansi deviation from linearity $>0,05$. Dengan demikian asumsi linieritas hubungan terpenuhi.

\section{Uji Multikolinieritas}

Dari rangkuman hasil uji multikolinieritas di atas, dapat dijelaskan bahwa variabel pengetahuan kewirausahaan (X1) mempunyai nilai VIF sebesari 1,947, variabel pengalaman prakerin (X2) mempunyai nilai VIF sebesar 1,790 dan variabel lingkungan keluarga mempunyai nilai VIF sebesar 1,555 . Dengan 
berpedoman pada ketentuan VIF $<10$ maka dapat disimpulkan bahwa tidak terjadi multikolinieritas antara ketiga variabel bebas pengetahuan kewirausahaan, pengalaman prakerin dan lingkungan keluarga.

\section{Analisis Data}

\section{Uji Hipotesis Pertama}

Hipotesis pertama, pengetahuan kewirausahaan mempunyai pengaruh positif dan signifikan terhadap kesiapan berwirausaha siswa SMK Kelas XII Kompetensi Keahlian Teknik Komputer dan Jaringan. Hipotesis ini untuk melihat pengaruh pengetahuan kewirausahaan terhadap kesiapan berwirausaha.

Tabel 2. Rangkuman Variabel X1 terhadap Y

\begin{tabular}{|c|c|c|c|c|}
\hline \multirow[t]{2}{*}{ Model } & \multicolumn{2}{|c|}{$\begin{array}{l}\text { Unstandard } \\
\text { coefficients }\end{array}$} & \multirow[t]{2}{*}{$\mathrm{t}$} & \multirow[t]{2}{*}{ sig } \\
\hline & B & Std. Error & & \\
\hline $\mathrm{X} 1$ & 0,536 & 0,043 & 12,496 & 0,000 \\
\hline
\end{tabular}

Tabel 2 diatas Merupakan hasil analisis regresi sederhana yang menunjukan koefisien regresi untuk pengetahuan kewirausahaan (X1) adalah 0,536 yang bernilai posistif. Berarti kesiapan berwirausaha akan meningkat apabila pengetahuan kewirausahaan ditingkatkan. Semakin tinggi pengetahuan kewirausahaan, semakin tinggi pula kesiapan berwirausahanya. Nilai probabilitas pada kolom sig adalah 0,000 , nilai $\mathrm{p}<0,05$ dapat diartikan bahwa pengaruh pengetahuan kewirausahaan terhadap kesiapan berwirausaha signifikan. Sehingga dari hasil analisis regresi ganda dapat disimpulkan bahwa pengetahuan kewirausahaan memberi pengaruh positif dan signifikan terhadap kesiapan berwirausaha. Dengan demikian hipotesis pertama yang menyatakan pengetahuan kewirausahaan mempunyai pengaruh positif dan signifikan terhadap kesiapan berwirausaha siswa SMK Kelas XII Kompetensi Keahlian Teknik Komputer dan Jaringan terbukti.

Tabel 3. Variabel X1 terhdap Y

\begin{tabular}{ccccc}
\hline Model & $\mathrm{R}$ & $R$ Square & $\begin{array}{c}\text { Adjust } \\
R \\
\text { Square }\end{array}$ & $\begin{array}{c}\text { Std. Error } \\
\text { of The } \\
\text { Estimate }\end{array}$ \\
\hline $\mathrm{X} 1$ & 0,735 & 0,540 & 0,537 & 3,437 \\
\hline
\end{tabular}

Pada tabel 3 di atas dapat diketahui besarnya koefisien korelasi (r) antara pengetahuan kewirausahaan dengan kesiapan berwirausaha adalah 0,735 . Dengan demikian berarti terdapat tingkat hubungan yang kuat antara pengetahuan kewirausahaan dengan kesiapan berwirausaha. Berdasarkan tabel 3 Juga diperoleh koefisien determinasi $\left(\mathrm{r}^{2}\right)$ yaitu 0,540 . Hal ini berarti kontribusi pengetahuan kewirausahaan terhadap kesiapan berwirausaha sebesar $54 \%$, sedangkan $46 \%$ dipengaruhi variabel lain.

\section{Uji Hipotesis Kedua}

Hipotesis kedua, pengalaman praktik kerja industri mempunyai pengaruh positif dan signifikan terhadap kesiapan berwirausaha. Hipotesis ini diuji menggunakan teknik regresi sederhana, untuk melihat pengaruh pengalaman praktik kerja industri terhadap kesiapan berwirausaha. Analisis regresi dapat dilihat pada Tabel 4.

Tabel 4. Variabel Pengalaman Prakerin Terhadap Kesiapan Berwirausaha

\begin{tabular}{ccccc}
\hline Variabel & \multicolumn{2}{c}{$\begin{array}{c}\text { Unstandard } \\
\text { coefficients }\end{array}$} & $\mathrm{T}$ & sig \\
\cline { 1 - 3 } $\mathrm{X} 2$ & $\mathrm{~B}$ & Std. Error & & \\
\cline { 2 - 4 } & 0,779 & 0,098 & 7,932 & 0,000 \\
\hline
\end{tabular}

Tabel 4 merupakan hasil analisis regresi sederhana yang menunjukan koefisien regresi untuk pengalaman prakerin (X2) adalah 0,779 yang bernilai posistif. Berarti kesiapan berwirausaha akan meningkat apabila pengalaman prakerin ditingkatkan. Semakin tinggi pengalaman prakerin, semakin tinggi pula kesiapan berwirausahanya. Nilai probabilitas pada kolom sig adalah 0,000 , nilai $\mathrm{p}<0,05$ dapat diartikan bahwa pengaruh pengalaman prakerin terhadap kesiapan berwirausaha signifikan. Sehingga dari hasil analisis regresi sederhana dapat disimpulkan bahwa pengalaman prakerin memberi pengaruh positif dan signifikan terhadap kesiapan berwirausaha. Dengan demikian hipotesis kedua yang menyatakan pengalaman praktik kerja industri mempunyai pengaruh positif dan signifikan terhadap kesiapan berwirausaha siswa SMK Kelas XII Kompetensi Keahlian Teknik Komputer dan Jaringan terbukti. 


\section{Uji Hipotesis Ketiga}

Hipotesis ketiga, lingkungan keluarga mempunyai pengaruh positif dan signifikan terhadap kesiapan berwirausaha. Hipotesis ini diuji menggunakan teknik regresi sederhana, untuk melihat pengaruh lingkungan keluarga terhadap kesiapan berwirausaha.

Tabel 5. Variabel Lingkungan Keluarga Terhadap Kesiapan Berwirausaha

\begin{tabular}{ccccc}
\hline Variabel & \multicolumn{2}{c}{$\begin{array}{c}\text { Unstandard } \\
\text { coefficients }\end{array}$} & t & sig \\
\cline { 1 - 3 } $\mathrm{X} 2$ & $\mathrm{~B}$ & Std. Error & & \\
\cline { 2 - 5 } & 0,371 & 0,057 & 6,549 & 0,000 \\
\hline
\end{tabular}

Tabel 5 merupakan hasil analisis regresi sederhana yang menunjukan koefisien regresi untuk lingkungan keluarga (X3) adalah 0,371 yang bernilai posistif. Berarti kesiapan berwirausaha akan meningkat apabila lingkungan keluarga ditingkatkan. Semakin tinggi lingkungan keluarga, semakin tinggi pula kesiapan berwirausahanya. Nilai probabilitas pada kolom sig adalah 0,000 , nilai $p<0,05$ dapat diartikan bahwa pengaruh lingkungan keluarga terhadap kesiapan berwirausaha signifikan. Sehingga dari hasil analisis regresi sederhana dapat disimpulkan bahwa lingkungan keluarga memberi pengaruh positif dan signifikan terhadap kesiapan berwirausaha. Dengan demikian hipotesis kedua yang menyatakan lingkungan keluarga mempunyai pengaruh positif dan signifikan terhadap kesiapan berwirausaha siswa SMK Kelas XII Kompetensi Keahlian Teknik Komputer dan Jaringan terbukti.

Korelasi dan kontribusi lingkungan keluarga terhadap kesiapan berwirausaha dapat diketahui dari hasil teknik analisis regresi sederhana lingkungan keluarga terhadap kesiapan berwirausaha

Tabel 6. Variabel Lingkungan Keluarga Terhadap Kesiapan Berwirausaha

\begin{tabular}{ccccc}
\hline Model & $\mathrm{R}$ & $\begin{array}{c}R \\
\text { Square }\end{array}$ & $\begin{array}{c}\text { Adjust } \\
R \\
\text { Square }\end{array}$ & $\begin{array}{c}\text { Std. Error } \\
\text { of The } \\
\text { Estimate }\end{array}$ \\
\hline $\mathrm{X} 3$ & 0,494 & 0,244 & 0,238 & 4,407 \\
\hline
\end{tabular}

Pada tabel 6 di atas dapat diketahui besarnya koefisien korelasi (r) antara lingkungan keluarga dengan kesiapan berwirausaha adalah 0,494. Dengan demikian berarti terdapat tingkat hubungan yang sedang antara lingkungan keluarga dengan kesiapan berwirausaha. Berdasarkan tabel 6 juga diperoleh koefisien determinasi $\left(\mathrm{r}^{2}\right)$ yaitu 0,244 . Hal ini berarti kontribusi lingkungan keluarga terhadap kesiapan berwirausaha sebesar $24,4 \%$, sedangkan 75,6\% dipengaruhi variabel lain.

\section{Uji Hipotesis Keempat}

Hipotesis keempat, pengetahuan kewirausahaan, pengalaman praktik kerja industri, dan lingkungan keluarga secara bersama-sama mempunyai pengaruh positif dan signifikan terhadap kesiapan berwirausaha siswa SMK Kelas XII Kompetensi Keahlian Teknik Komputer dan Jaringan. Hipotesis ini diuji dengan menggunakan teknik analisis regresi ganda. Rangkuman hasil analisis regresi ganda disajikan pada Tabel 7.

Tabel 7. Hasil Analisis Regresi Ganda Variabel X1, X2, X3 Terhadap Y

\begin{tabular}{cccccc}
\hline & R & R Square & $\begin{array}{c}\text { Adjust } \\
\mathrm{R}^{2}\end{array}$ & F & Sig \\
\hline Regresi & 0,749 & 0,560 & 0,550 & 55,674 & 0,000 \\
\hline
\end{tabular}

Tabel 7 di atas merupakan hasil analisis regresi ganda yang menunjukan koefisien regresi untuk pengetahuan kewirausahaan, pengalaman prakerin, dan lingkungan keluarga adalah 0,749 yang bernilai posistif. Berarti terdapat tingkat hubungan yang kuat antara pengetahuan kewirausahaan, pengalaman prakerin, dan lingkungan keluarga secara bersama-sama terhadap kesiapan berwirausaha. Nilai probabilitas pada kolom sig adalah 0,000 , nilai $\mathrm{p}<0,05$ dapat diartikan bahwa pengaruh secara bersama-sama pengetahuan kewirausahaan, pengalaman prakerin, dan lingkungan keluarga terhadap kesiapan berwirausaha signifikan. Sehingga dari hasil regresi ganda dapat disimpulkan bahwa pengetahuan kewirausahaan, pengalaman prakerin, dan lingkungan keluarga secara bersama-sama memberi pengaruh positif dan signifikan terhadap kesiapan berwirausaha. Dengan demikian hipotesis keempat dapat terbukti. 
Dari analisis regresi ganda juga didapatkan besarnya kontribusi ketiga variabel bebas melalui nilai R Square sebesar 0,560, dengan demikian dapat disimpulkan bahwa pengetahuan kewirausahaan, pengalaman prakerin, dan lingkungan keluarga secara bersama-sama memiliki pengaruh sebesar $56 \%$ terhadap kesiapan berwirausaha. Sedangkan $44 \%$ dipengaruhi oleh variabel lain yaitu variabel-variabel yang tidak diteliti dalam penelitian ini.

Penelitian ini bertujuan untuk mengetahui pengaruh pengetahuan kewirausahaan, pengalaman praktik kerja industri, dan lingkungan keluarga terhadap kesiapan berwirausaha siswa SMK kompetensi keahlian teknik komputer dan jaringan di Kabupaten Gunungkidul. Berdasarkan data penelitian yang dianalisis, maka dapat dibahas sebagai berikut:

\section{Kesiapan Berwirausaha Siswa SMK Kompetensi Keahlian Teknik Komputer dan Jaringan di Kabupaten Gunungkidul}

Hasil penelitian ini menunjukan bahwa tingkat kesiapan berwirausaha siswa SMK kompetensi keahlian teknik komputer dan jaringan di kabupaten Gunungkidul mempunyai kecenderungan sangat tinggi. Hal ini bisa dilihat dari hasil analisis deskriptif bahwa sebanyak 91 siswa dari 135 memperoleh skor sangat tinggi dan 44 siswa dari 135 mendapatkan skor tinggi. Dari hasil penelitian ini memberikan gambaran bahwa sebagian siswa telah memiliki kesiapan untuk berwirausaha. Hal ini disebabkan karena siswa telah mengenal terhadap diri mereka sendiri serta didukung oleh pengetahuan kewirausahaan, pengalaman praktik kerja industri serta lingkungan keluarga.

Siswa yang dapat mengenali dirinya sendiri tentu dapat mengetahui apa yang menjadi tujuan hidupnya. Ia menyadari kemampuan dan bakat-bakatnya serta tahu bagaimana menggunakannya demi mencapai tujuan tersebut. Pengenalan diri merupakan modal awal untuk dapat mengidentifikasi dan mengenali lingkungan, mengindera peluangpeluang bisnis dan mendayagunakan sumbersumber daya lingkungan dalam batas resiko yang tertanggungkan untuk memperoleh nilai tambah.

Untuk mendukung dan memotivasi siswa agar lebih siap dan berani dalam mem- buka usaha dilakukan dengan meningkatkan pembelajaran kewirausahaan di sekolah agar lebih tepat mengenai sasaran kepada siswa untuk termotivasi mendirikan sebuah usaha. Pelaksanaan praktik kerja industri lebih ditingkatkan untuk menambah pengalaman dalam berwirausaha. Dengan prakerin anak dapat mengenal, mempraktikan, dan belajar mengelola sebuah usaha. Hal yang tidak kalah penting adalah dukungan dari orang tua untuk selalu memberikan motivasi dan wawasan mengenai sebuah usaha.

\section{Pengaruh Pengetahuan Kewirausahaan terhadap Kesiapan Berwirausaha Siswa SMK Kelas XII Kompetensi Keahlian Teknik Komputer dan Jaringan di Kabupaten Gunungkidul}

Sikap dan perilaku sebagai seorang wirausahawan merupakan pemahaman yang paling dominan dalam penelitian ini. Seorang wirausaha harus mempunyai sikap mental yang tinggi, kemauan yang keras serta pantang menyerah. Dari sikap ini maka akan memunculkan kepercayaan diri yang tinggi sehingga wirausahawan dapat menentukan visi usahanya. Dengan adanya visi dari usahanya tersebut maka wirausahawan akan berpikir secara kreatif dan inovatif untuk mencapai visinya tersebut.

Dari hasil pengolahan data diketahui bahwa pengetahuan kewirausahaan memiliki pengaruh positif terhadap kesiapan berwirausaha siswa. Penelitian ini menunjukkan bahwa semakin banyak pengetahuan kewirausahaan yang dikuasai siswa, maka semakin siap pula siswa untuk berwirausaha.

Persepsi responden mengenai pengetahuan kewirausahaan termasuk dalam kategori tinggi. Artinya secara umum responden memiliki pengetahuan kewirausahaan yang amat baik. Namun secara rinci, responden belum memahami pembuatan aspek-aspek perencanaan usaha selain itu keberanian untuk mengambil keputusan memulai sebuah usaha juga masih menjadi pertimbangan dari responden.

Hasil penelitian ini mengungkap bahwa pengaruh pengetahuan kewirausahaan $\left(\mathrm{X}_{1}\right)$ terhadap kesiapan siswa untuk berwirausaha (Y), dengan menggunakan regresi sederhana didapatkan nilai koefisien positif sebesar 
0,536 nilai signifikansi sebesar 0,000 dan harga $R$ Square sebesar 0, Artinya bahwa semakin banyak pengetahuan kewirausahaan yang dikuasai siswa maka kesiapan siswa untuk berwirausaha akan semakin meningkat. Adapun sumbangan efektif pengetahuan kewirausahaan terhadap kesiapan siswa untuk berwirausaha sebesar $54 \%$ sedangkan sisanya yaitu $46 \%$ dipengaruhi oleh variabel lain. Dengan demikian dapat disimpulkan bahwa semakin banyak pengetahuan kewirausahaan yang dikuasai siswa maka akan semakin tinggi/besar kesiapan siswa untuk berwirausaha.

\section{Pengaruh Pengalaman Praktik Kerja Industri Terhadap Kesiapan Berwirausaha Siswa SMK Kelas XII Kompetensi Keahlian Teknik Komputer dan Jaringan di Kabupaten Gunungkidul.}

Dari hasil pengolahan data diketahui bahwa pengalaman praktik kerja industri memiliki pengaruh yang searah dengan kesiapan berwirausaha. Penelitian ini menunjukkan bahwa semakin banyak pengalaman yang di dapatkan siswa dalam prakerin, maka semakin tinggi pula kesiapan berwirausaha, demikian pula sebaliknya, semakin rendah pengalaman prakerin, maka semakin rendah pula kesiapan berwirausaha.

Persepsi responden terhadap pengalaman praktik kerja industri berada dalam kategori tinggi, artinya proses pelaksanaan praktik kerja industri memberikan banyak manfaat bagi responden. Selain mendapatkan manfaat dari prakerin siswa juga mendapatkan ilmu tentang pengelolaan dari sebuah usaha, oleh karena itu, perlu ditingkatkan kerjasama dari pihak sekolah dan industri untuk mendidik siswa menjadi seorang wirausaha.

Hasil penelitian ini mengungkap bahwa pengaruh pengalaman praktik kerja industri $\left(\mathrm{X}_{2}\right)$ terhadap kesiapan siswa untuk berwirausaha (Y), dengan menggunakan regresi sederhana didapatkan nilai koefisien positif sebesar 0,779 nilai signifikansi sebesar 0,000 dan harga $R$ Square sebesar 0,321 (lihat tabel 13 dan 14). Artinya bahwa semakin banyak pengalaman praktik kerja industri yang didapatkan siswa maka kesiapan siswa untuk berwirausaha akan semakin meningkat. Ada- pun sumbangan efektif pengalaman praktik kerja industri terhadap kesiapan siswa untuk berwirausaha sebesar $32,1 \%$ sedangkan sisanya yaitu $67,9 \%$ dipengaruhi oleh variabel lain. Dengan demikian dapat disimpulkan bahwa semakin tinggi/besar pengalaman praktik kerja industri yang didapatkan siswa maka akan semakin tinggi/besar kesiapan siswa untuk berwirausaha.

\section{Pengaruh Lingkungan Keluarga terhadap Kesiapan Berwirausaha Siswa SMK Kelas XII Kompetensi Keahlian Teknik Komputer dan Jaringan di Kabupaten Gunungkidul}

Secara deskriptif, hasil penelitian ini mengungkapkan lingkungan keluarga siswa SMK Kompetensi Keahlian Teknik Komputer dan Jaringan di kabupaten Gunungkidul. Berdasarkan tingkat kecenderungannya, pengalaman praktik kerja industri siswa memiliki kategori sangat tinggi sebesar 29,6\% (40 siswa), kategori tinggi $60 \%$ (81 siswa), kategori rendah 9,7\% (13 siswa) dan kategori sangat rendah sebesar 0,7\% (1 siswa). Adapun distribusi frekuensi variabel lingkungan keluarga siswa untuk berwirausaha dapat dilihat pada tabel 7 halaman 59. Kemudian sesuai coefficients yang dapat dilihat pada tabel 15 halaman 67, maka persamaan garis regresi untuk $\mathrm{X}_{3}$ terhadap $\mathrm{Y}$ adalah:

$$
\mathrm{Y}=0,371 \mathrm{X}_{3}+51281
$$

Hasil penelitian ini mengungkap bahwa pengaruh lingkungan keluarga $\left(\mathrm{X}_{3}\right)$ terhadap kesiapan siswa untuk berwirausaha (Y), dengan menggunakan regresi sederhana didapatkan nilai koefisien positif sebesar 0,371 nilai signifikansi sebesar 0,000 dan harga $R$ Square sebesar 0,244. Artinya bahwa semakin tinggi dukungan lingkungan keluarga untuk berwirausaha maka kesiapan siswa untuk berwirausaha akan semakin meningkat. Adapun sumbangan efektif dukungan keluarga untuk berwirausaha terhadap kesiapan siswa untuk berwirausaha sebesar $24,4 \%$ sedangkan sisanya yaitu $75,6 \%$ dipengaruhi variabel lain. Dengan demikian dapat disimpulkan bahwa semakin tinggi/besar dukungan lingkungan keluarga maka akan semakin tinggi/besar kesiapan siswa untuk berwirausaha. 


\section{Pengaruh Pengetahuan Kewirausahaan, Pengalaman Praktik Kerja Industri, dan Lingkungan Keluarga terhadap Kesiapan Berwirausaha}

Hasil penelitian ini mengungkap bahwa pengaruh pengetahuan kewirausahaan $\left(\mathrm{X}_{1}\right)$, pengalaman praktik kerja industri $\left(\mathrm{X}_{2}\right)$, lingkungan keluarga $\left(X_{3}\right)$ terhadap kesiapan siswa untuk berwirausaha $(\mathrm{Y})$, dengan menggunakan regresi ganda didapatkan harga $R$ Square sebesar 0,560 . Artinya pengetahuan kewirausahaan, pengalaman praktik kerja industri, dan lingkungan keluarga secara bersama-sama memiliki pengaruh terhadap kesiapan berwirausaha siswa sebesar 56\%. Sedangkan $46 \%$ dipengaruhi oleh variabel lain yang tidak diteliti dalam Penelitian ini. Kemudian sesuai coefficients yang dapat dilihat pada tabel 17, maka persamaan garis regresi ganda untuk $X_{1}$, $\mathrm{X}_{2}, \mathrm{X}_{3}$ terhadap $\mathrm{Y}$ adalah: $\mathrm{Y}=0,435 \mathrm{X}_{1}+$ $0,196 X_{2}+0,063 X_{3}+21,904$.

\section{SIMPULAN DAN SARAN}

\section{Simpulan}

Kesiapan berwirausaha siswa SMK kompetensi keahlian Teknik Komputer dan Jaringan di Gunungkidul termasuk dalam kategori sangat tinggi. Hal ini disebabkan karena semua faktor yang mempengaruhi kesiapan berwirausaha siswa dalam penelitian ini dapat mendukung dengan baik. Faktor yang dimaksud adalah pengetahuan kewirausahaan, pengalaman praktik kerja industry, dan lingkungan keluarga.

Terdapat pengaruh yang positif dan signifikan antara pengetahuan kewirausahaan terhadap kesiapan berwirausaha siswa SMK kompetensi keahlian teknik komputer dan jaringan di Kabupaten Gunungkidul $\left(\mathrm{r}_{\mathrm{x} 1 \mathrm{y}}=\right.$ $0,73 ; \mathrm{p}<0,05)$. Dari hasil analisis tersebut pengetahuan kewirausahaan memberikan sumbangan terhadap kesiapan berwirausaha sebesar $54 \%$.

Terdapat pengaruh yang positif dan signifikan antara pengalaman prakerin terhadap kesiapan berwirausaha siswa SMK kompetensi keahlian teknik komputer dan jaringan di kabupaten Gunungkidul $\left(\mathrm{r}_{\mathrm{x} 2 \mathrm{y}}=\right.$ $0,56 ; \mathrm{p}<0,05)$. Dari hasil analisis tersebut pengalaman praktik kerja industri memberi- kan sumbangan terhadap kesiapan berwirausaha sebesar $32,1 \%$.

Terdapat pengaruh yang positif dan signifikan antara lingkungan keluarga terhadap kesiapan berwirausaha siswa SMK kompetensi keahlian teknik komputer dan jaringan di kabupaten Gunungkidul $\left(\mathrm{r}_{\mathrm{x} 3 \mathrm{y}}=\right.$ $0,49 ; \mathrm{p}<0,05)$. Dari hasil analisis tersebut pengalaman praktik kerja industri memberikan sumbangan terhadap kesiapan berwirausaha sebesar $24,4 \%$.

Terdapat pengaruh yang positif dan signifikan secara bersama-sama antara pengetahuan kewirausahaan, pengalaman praktik kerja indsutri dan lingkungan keluarga $\left(r_{x 1 y, x 2 y, x 3 y}\right)$ terhadap kesiapan berwirausaha siswa SMK kompetensi keahlian teknik komputer dan jaringan di kabupaten Gunungkidul $\left(r_{x 1 y, x 2 y, x 3 y}=0,74 ; p<0,05\right)$. Kuatnya pengaruh pengetahuan kewirausahaan, pengalaman praktik kerja industri, dan lingkungan keluarga secara bersama-sama terhadap kesiapan berwirausaha teramati dari besarnya koefisien determinasi $(R)^{2}=0,560$; sehingga memberikan sumbangan efektif sebesar $56 \%$ terhadap kesiapan berwirausaha, sehingga persamaan garis regresi ganda untuk $\mathrm{X}_{1}, \mathrm{X}_{2}, \mathrm{X}_{3}$ terhadap $\mathrm{Y}$ adalah: $\mathrm{Y}=0,435 \mathrm{X}_{1}+0,196 \mathrm{X}_{2}+0,063 \mathrm{X}_{3}$ $+21,904$.

\section{Implikasi}

Dari hasil penelitian ini memberikan gambaran bahwa kesiapan berwirausaha siswa SMK kompetensi keahlian teknik komputer dan jaringan di kabupaten Gunungkidul menunjukan kecenderungan kearah positif dan harapan yang menggembirakan. Hal ini berimplikasi pada upaya untuk meningkatkan kesiapan berwirausaha siswa dengan melibatkan seluruh unsur mulai dari sekolah, pemerintah, orang tua, DU/DI dan masyarakat sekitar secara sinergis.

Sarana kegiatan pembelajaran kewirausahaan, kegiatan prakerin dan dukungan dari orangtua juga mempunyai pengaruh positf dan signifikan terhadap kesiapan berwirausaha siswa. Hal ini memberikan informasi bahwa ke depan perlu adanya pembinaan yang serius terhadap kegiatan praktik tersebut, dengan harapan pada akhirnya kesiapan siswa untuk berwirausaha semakin lebih baik. Demikian juga dukungan dari lingkungan keluarga sangat penting perananya, hal ini karena 
pembentukan sikap kepribadian seorang individu (anak) terbentuk dari warisan sifat-sifat, bakat orang tua dan lingkungan dimana mereka berada dan berkembang.

\section{Saran}

Pengetahuan kewirausahaan berdasarkan skor responden masuk kategori tinggi. Artinya pengetahuan kewirausahaan yang dimiliki responden dinilai cukup tinggi. Namun dalam upaya meningkatkan kesiapan berwirausaha diperlukan faktor penarik yang berupa kesempatan berwirausaha. Kesempatan berwirausaha dapat dilakukan dengan kesempatan mengaplikasikan pembelajaran kewirausahaan di keluarga.

Berdasarkan pada pengolohan hasil penelitian pada variabel pengalaman praktik kerja industri, dimana kedisiplinan siswa selama melaksanakan praktik kerja industri memperoleh skor terendah maka para siswa hendaknya mengikuti seluruh program praktik kerja industri dengan sungguh-sungguh dan penuh disiplin serta berani memberikan ide atau gagasan demi kemajuan usaha di tempat praktik sebagai bekal setelah lulus sekolah, baik saat bekerja pada orang lain maupun saat membuka lapangan kerja baru melalui wirausaha.

Lingkungan keluarga merupakan faktor penting yang mempengaruhi kesiapan berwirausaha. Oleh karena itu, pihak keluarga diharapkan dapat mendidik, mengarahkan wawasan mengenai wirausaha sejak dini.
Penelitian ini hanya mengetahui besarnya pengaruh pengetahuan kewirausahaan, lingkungan keluarga dan pengalaman praktik kerja industri terhadap kesiapan berwirausaha siswa. Untuk peneliti yang akan datang disarankan meneliti sampai perilaku riil siswa dalam berwirausaha, sehingga diperoleh kerangka model yang lengkap.

\section{DAFTAR PUSTAKA}

Azwar, S. (2012). Penyusunan skala psikologi. Yogyakarta: Pustaka Pelajar.

Depdiknas. (1990). Peraturan Pemerintah RI Nomor 29, Tahun 1990, Tentang Pendidikan Menengah.

Dikmenjur. (2008). Pelaksanaan prakerin. Diambil pada tanggal 20 januari 2012, dari http://www.geocities.com/dit_ dikmenjur/prosedur_Prakerin.html.

Sudrajat, Akhmad. (22 januari 2008). Komponen-komponen kurikulum. Diambil pada tanggal 2 agustus 2012, dari Error! Hyperlink reference not valid.

Sugiyono. (2011). Metode penelitian pendidikan. Bandung: Alfabeta

Sugiyono. (2012). Statistika untuk penelitian. Bandung: Alfabeta. 